\title{
p53 expression in human small intestinal tumors
}

\author{
D.A. SPANDIDOS ${ }^{1,2}$, V. ZOUMPOURLIS ${ }^{1,2}$, V. GORGOULIS ${ }^{3}$ and N.C. GOURTSOYIANNIS ${ }^{1,4}$ \\ ${ }^{1}$ Medical School, University of Crete, Heraklion; ${ }^{2}$ National Hellenic Research Foundation, Athens; \\ ${ }^{3}$ Red Cross Hospital, Athens; ${ }^{4}$ Air Forces General and V.A. Hospital, Athens, Greece
}

Received June 10, 1994; Accepted July 8, 1994

\begin{abstract}
Expression of the tumor supressor gene product p53 in thirteen human small intestinal tumors was examined employing an immunohistochemical technique. The level of p53 was analysed using the monoclonal antibody pAb240. Six out of thirteen tumors (46\%) including one lymphoma, one angiosarcoma of the jejunum, one leiomyosarcoma, one adenocarcinoma of the small intestine and two metastatic adenocarcinomas of the colon were found to have p53 overexpression. This is the first demonstration of $\mathrm{p} 53$ expression in small intestinal tumors. These results indicate that the p53 gene may be involved in the pathogenesis of small intestinal tumors.
\end{abstract}

\section{Introduction}

Small intestine tumors are rare in comparison with those of the colon, although the former represents the largest part of the length and mucosal surface of the bowel $(1,2)$. They consist of a wide range of both benign and malignant neoplasms of different origin $(3,4)$. The information concerning the molecular basis of these tumors is limited (5).

In a previous study we examined the ras oncogene family activation and gene product expression in a series of small intestinal tumors. We found $\mathrm{H}$-ras mutations and elevated ras p 21 oncoprotein in $30 \%$ and $62 \%$ of the cases respectively suggesting a possible role of ras oncogene in the pathogenesis of these tumors (6).

This study, to our knowlege is the first to assess p53 expression in small intestine tumors and represents the continuation of our previous work in the same series of neoplasms where ras expression was studied (6).

p53 expression was examined with the microwave post fixation streptavidin - Horse Radish Peroxidase (HRP) immunohistochemical method using the monoclonal antibody pAb240 (7).

Correspondence to: Professor D.A. Spandidos, Institute of Biological Research and Biotechnology, National Hellenic Research Foundation, 48 Vas. Constantinou Ave., Athens 116 35, Greece

Key words: p53 gene, small intestinal tumors

\section{Materials and methods}

Tissue specimens. Sections from paraffin-embedded tissue from tumors of human small intestine were obtained from the Air Forces General and V.A. Hospital, Athens and the University Hospital, Heraklion, Greece. The histological types of the tumors are shown in Table I.

Immunohistochemistry. Immunohistochemical analysis of p53 was undertaken using the monoclonal antibody (mouse) pAb240 (Oncogene Science) (7). Serial sections were cut from all paraffin blocks at $5 \mu \mathrm{m}$ and mounted on Vectabond treated glass slides. The slides were air dried at room temperature for at least 24 hours. Then sections were dewaxed, rehydrated and endogenous peroxidase activity was blocked with $0.6 \% \mathrm{H}_{2} \mathrm{O}_{2}$ in $80 \%$ methanol for 20 min. After the sections were washed with double distilled water $\left(\mathrm{ddH}_{2} \mathrm{O}\right)$ and placed in a plastic container (Sigma) filled with the following solution: $0.01 \mathrm{M}$ sodium citrate $\mathrm{Na}_{3} \mathrm{C}_{6} \mathrm{H}_{5} \mathrm{O}_{7} \cdot \mathrm{H}_{2} \mathrm{O}$, $0.01 \mathrm{M} \mathrm{HCl} /$ Sodium citrate buffer $\mathrm{pH}$ 6.0. The jar was irradiated in a BioRad Polaron $\mathrm{H} 2500$ microwave processor (BioRad, Watford, Hertfordshire, UK) for $10 \mathrm{~min}(2 \times 5) \mathrm{min}$ at a power output equivalent to $600 \mathrm{~W}$ ensuring that there had been no loss of buffer during the first cycle. It has been shown that the above treatment is superior in unmasking p53 protein, in routine material, compared to conventional enzymatic tratment (8).

The sections were then rinsed in $\mathrm{ddH}_{2} \mathrm{O}$ water and TBS (Tris-buffered saline $(0.05 \mathrm{~mol} / 1 \mathrm{Tris}-\mathrm{HCl}, 0.1 \mathrm{~mol} / \mathrm{l} \mathrm{NaCl}$, $\mathrm{pH}$ 7.2). The second incubation was in biotinylated rabbit anti-mouse ( $\mathrm{Fab}\left(\mathrm{ab}^{\prime}\right)_{2}$ fragment) (Dako, Denmark) diluted 1:200 TBS for $25 \mathrm{~min}$ and the third, after a wash with $\mathrm{ddH}_{2} \mathrm{O}$ and TBS, was streptavidin-HRP (Dako, Denmark) diluted 1:300 TBS for $25 \mathrm{~min}$. Signal was developed using diaminobenzidine (DAB) and hydrogen peroxide. After slides were air dried at $37^{\circ} \mathrm{C}$ counterstained, dehydrated and mounted. p53-expressing lung carcinomas were used as positive controls and as negative control, mouse IgG1 mAb of unrelated specificity and the IgG fraction of normal rabbit serum. All p53 positive nuclei were counted on the specimens and the following semi-quantitative method was used: $( \pm)=$ negative or equivocal $(<5 \%$ positive cells $),(+)=$ weak/moderate $(5-50 \%$ positivity) and $(++)=$ intensely positive ( $>50 \%$ positivity). 
Table I. Immunohistochemical staining of p53 protein in 13 human small intestinal tumors.

\begin{tabular}{ll}
\hline Type of tumor & $\begin{array}{l}\text { Staining } \\
\text { intensity } \\
\end{array}$ \\
& $\pm \quad+\quad++$ \\
\hline 1. Hyperplastic - metaplastic polyp & \pm \\
2. Adenomatous and papillary polyp & \pm \\
of duedenum & \pm \\
3. Adenomatous polyp of the small intestine & \pm \\
4. Brunner's gland adenoma of the duedenum & \pm \\
5. Neurilemoma & \pm \\
6. Leiomyoma & \pm \\
7. Carcinoid & \pm+ \\
8. Lymphoma & \\
9. Angiosarcoma of the jejunum & + \\
10. Leiomyosarcoma & ++ \\
11. Adenocarcinoma of the small intestine \\
12. Metastatic adenocarcinoma of the colon \\
13. Metastatic adenocarcinoma of the colon \\
\hline
\end{tabular}

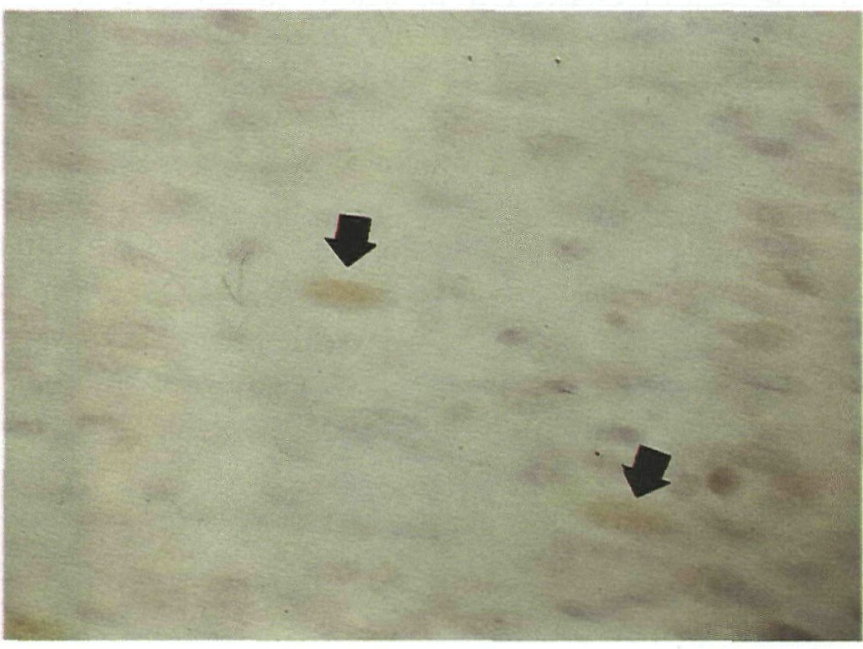

Figure 1. Weak p53 immunodetection, stained with pAb240, in leiomyosarcoma (arrows) (X400).

\section{Results}

Thirteen small intestine tumors were assessed for p53 levels of expression using the monoclonal antibody pAb240. 6/13 $(46 \%)$ of the tumors showed immunoreactivity for p53 protein (Table I). The pattern of immunoreactivity was exclusively nuclear (Figs. 1, 2 and 3) Interestigly there was p53 reactivity in normal epithelium (Fig. 4). Variations were observed in the persentage of reactive cells ranging from 5 to $90 \%$ (Table I). Variations in the intensity of staining between nuclei of the same tumor were also observed (Figs. 1, 2 and 3).

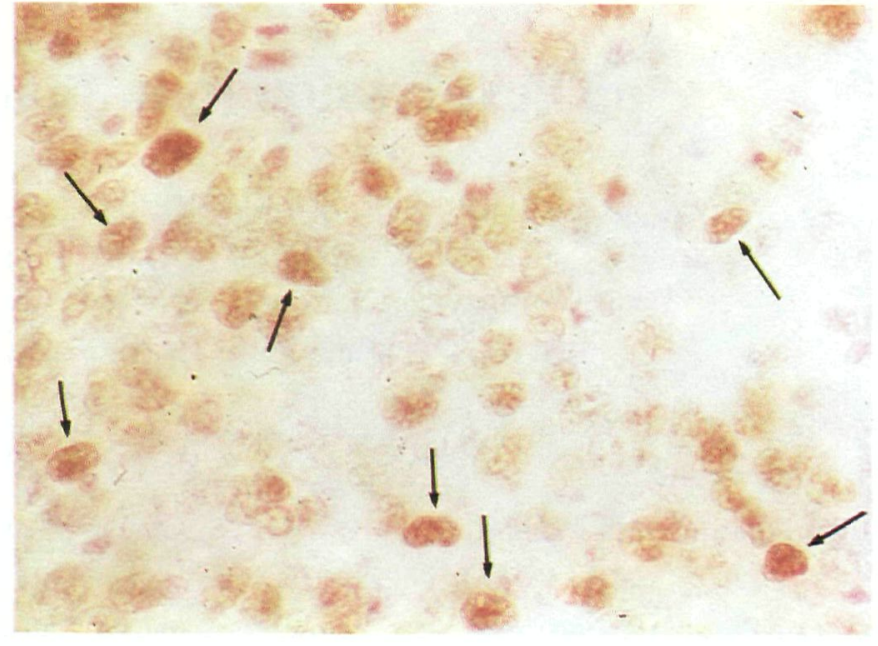

Figure 2. Strong p53 immunodetection, stained with pAb240, in MALT lymphoma (arrows) (X400).

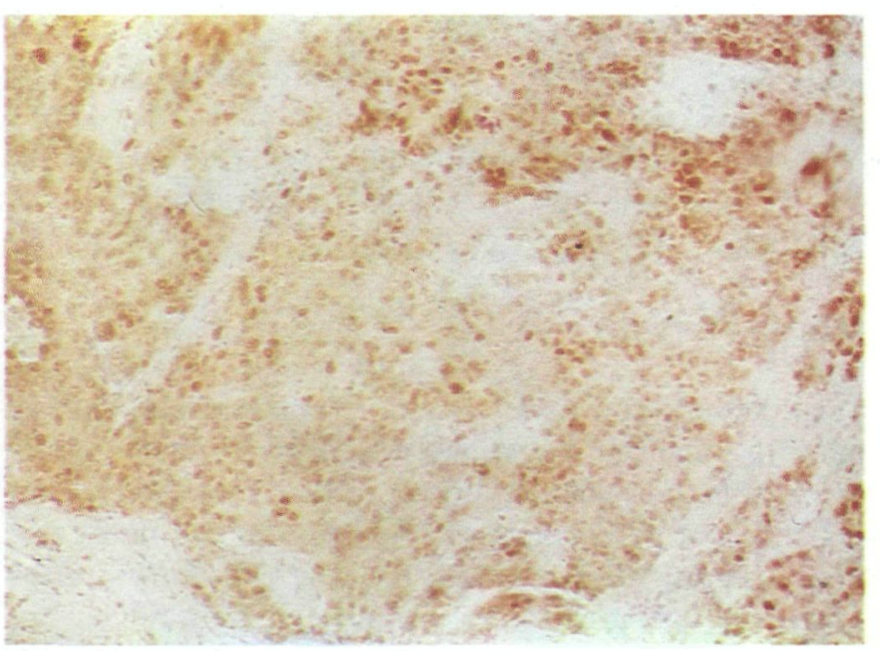

Figure 3. Strong p53 immunodetection, stained with pAb240 in an undifferentiated metastatic tumor from a large bowel carcinoma (X200).

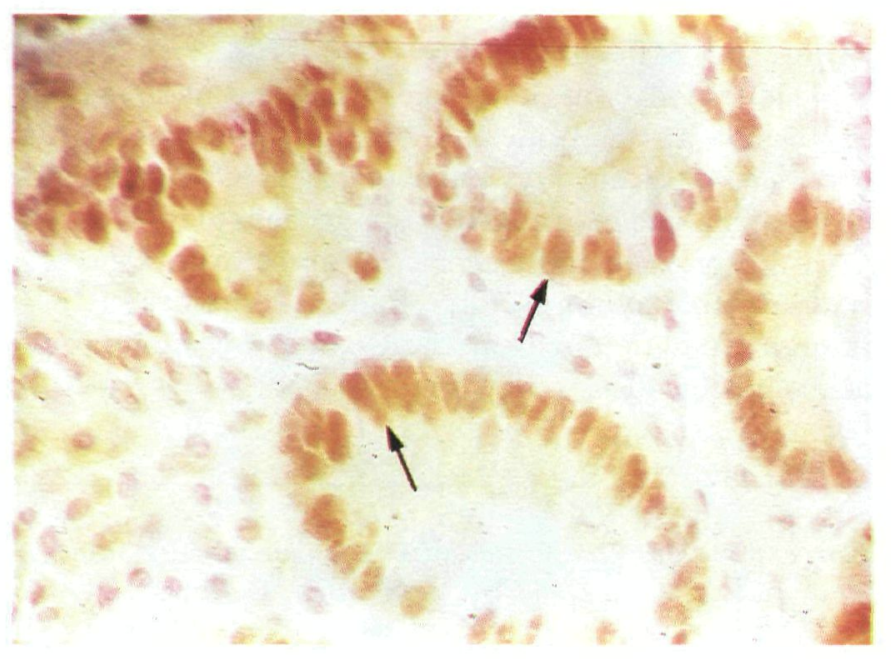

Figure 4. Strong p53 immunodetection stained with pAb240, in normal small intestine crypt (arrows) (X400). 


\section{Discussion}

Inactivation of tumor suppressor genes is involved in the pathogenesis of several human cancers (9). Such genes are the retinoblastoma $(\mathrm{Rb})$, the $\mathrm{p} 53$ and the $n m 23$ gene. The $\mathrm{p} 53$ gene encodes a nuclear protein which plays an important role in the regulation of normal cell growth (10).

Point mutations in the p53 gene result in an increased stability of the mutant protein, which can be detected by immunohistochemistry, whereas the wild-type p53 protein is undetectable, due to its short half-life (11). This approach has been used successfully to screen for $\mathrm{p} 53$ mutations in various tumors (12).

In this study we analysed the expression of $\mathrm{p} 53$ protein in 13 small intestine tumors with the use of the monoclonal antibody pAb240 which is known to recognize the mutant form of the $\mathrm{p} 53$.

Our analysis revealed that $\mathrm{p} 53$ nuclear phosphoprotein is overexpressed in $46 \%$ of small intestine tumors. Intense p53 expression (positivity $>50 \%$ of the cells) was observed only in the MALT lymphoma, and the two metastatic adenocarcinomas of the colon while the remaining positive cases showed moderate p53 staining (positivity $5-50 \%$ of the cells). None of the benign small intestine neoplasms showed p53 immunoreactivity although $\mathrm{p} 53$ protein was detected in rapidly proliferating crypt cells in normal intestine epithelium. The latter is in accordance with several studies which show inconsistencies between the accumulation of p53 protein identified by immunohistochemistry and direct sequencing of the gene (13). These reports propose that pAb240 positivity does not always equate with p53 mutations. In this case p 53 could be represented by the wildtype p53 protein. It has been shown previously that in rapidly proliferating cells the wild-type protein can be expressed at immunohistochemically detectable levels $(14,15)$.

Assuming that the immunohistochemical demonstration of p53, particularly by pAb240 indicates in most of the cases the mutant protein, these results show a role for p53 abnormalities in the malignant progression of small intestine neoplasms.

\section{References}

1. Garvin PJ, Heerman V, Kaminski DL and Willman VL: (eds.) Benign and Malignant Tumors of the Small Intestine. Year Book Medical Publishers, Chicago USA, pp1-46, 1979.

2. Goligher JC: Surgery of the Anus, Rectum and Colon. London, Baillere Tindall, 4th edit pp375-378, 1980.

3. Gourtsoyiannis NC, Bays D, Malemas M, Barouxis G and Liasis N: Radiological appearances of small intestinal leiomyomas. Clin Radiol 45: 94-103, 1992.

4. Gourtsoyiannis NC, Nolan DJ: Lymphoma of the small intestine: Radiological appearances. Clin Radiol 39: 639-645, 1988.

5. Andreassen A, Oyjord T, Hovig E, et al: p53 abnormalities in different subtypes of human sarcomas. Cancer Res 53: 468-471, 1993.

6. Spandidos DA, Liloglou T, Arvanitis D and Gourtsoyiannis NC: ras gene activation in human small intestinal tumors. Int $\mathrm{J}$ Oncol 2: 513-518, 1993

7. Gannon JN, Greaves R, Iggo R and Lane DP: Activating mutations in p53 produce a common conformational effect. A monoclonal antibody specific for the mutant form. EMBO J 9: 1595-1602, 1990.

8. Cattoretti G, Pileri S, Parravicini C, Becker MHG, Poggi S, Bifuleo C, Key G, Damato L, Sabattini E, Feudale E, Reynolds F, Gerdes J and Rilke F: Antigen unmasking on formalin-fixed paraffin-embedded tissue sections. J Pathol 171: 83-98, 1993.

9. Hollstein M, Sidransky D, Vogelstein B and Harris CC: p53 mutations in human cancers. Science 253: 49-53, 1991.

10. Zanbetti GP and Levine AJ: A comparison of the biological activities of wild-type and mutant p53. FASEB $\mathbf{J} 7: 855-865$, 1993.

11. Harris CC: Mutant p53 - The commonest genetic abnormality in human cancer? J Pathol 162: 5-6, 1990.

12. Nigro JM, Baker SJ, Preisinger AC, Jessup JM, Hostetter R, Cleary K, Bigner SH, Davidson N, Baylin S, Devilee P, Glover T, Collins FS, Weston A, Modali R, Harris CC and Vogelstein B: Mutations in the p53 gene occur in diverse human tumor types. Nature 342: 705-708, 1989.

13. Wynford-Thomas D: p53 in tumor pathology: can we trust immunochemistry? J Path 166: 329-330, 1992.

14. Mercer WE, Baserga R: Expression of the $\mathrm{p} 53$ protein during the cell cycle of human peripheral blood lymphocytes. Exp Cell Res 160: 31-46, 1985.

15. Milner J: A conformational hypothesis for the supressor and promoter functions of p53 in cell growth control and in cancer. Proc R Soc London Ser B 245: 139-145, 1991. 